Nena A. Vasojevićc ${ }^{*}$, Snežana Kirin¹, Predrag J. Marković ${ }^{2}$ ${ }^{*}$ Innovation Center of the Faculty of Mechanical Engineering, University of Belgrade, Serbia *Institute for Contemporary History, Belgrade, Serbia

\title{
Research on Scholarship Holders who Studied Abroad and Returned to Serbia
}

DOI: 10.7595/management.fon.2017.0020

\begin{abstract}
Knowledge has become the most valuable resource of the new era and the resource of the future. The intention of this study is to improve knowledge about the problem of migration of educated people from Serbia from the perspective of scholarship holders who, after spending some time abroad, returned to their country. The aim of this research is to show the profile of the scholarship holders of post-academic and post-graduate students, who studied abroad and then returned to Serbia. Their motives for departure and return, as well as their perception of integration into the work environment in Serbia and utilization of their knowledge is presented. Methods: For the purpose of this research a questionnaire was constructed which was distributed online. Collected data were analysed using statistical tools. Results: This research has shown that the primary motive for education abroad is the desire for personal development. It has also been shown that an important factor for the return of students from abroad is their expectation of comparative advantage in the labour market and their belief that they will be able to get a desired job. Apart from this, it is shown that the scholarship holders only partially use the acquired knowledge and thus do not have enough influence on the development of their organizations.Conclusion: The main research contribution is reflected in the improvement of the knowledge about the motivation of scholars to return from developed countries and in highlighting the problems scholarship holders have on coming home. Implications and research limitations: The results obtained can be generalised to countries that are undergoing or have recently commenced a transition, and are similar in cultural characteristics. The present contains certain limitations that must be taken into account while interpreting final results. The most significant constraint is the sample size, but the obtained results, especially the motives of the scientific experts for returning to this country, are extremely important and can be considered the starting basis for further research.
\end{abstract}

Key words: scholarship holders, motives for going abroad, motives for return, application of knowledge, job satisfaction

JEL Classification: I25, I23, C00

\section{Introduction}

Globalization has imposed ruthless competition in all areas of work. Related to that, knowledge has a strategic importance in developing unique capacities of the organisation and in providing it with sustainable competitive advantage in an interaction with all the activities of the business (Kirin \& Janovac \& Sedmak \& Jakic, 2014:264). Accelerated reorientation of developed economies in the world to invest in people is a definite confirmation of the place and role of human resources in their development strategies (Alagaraja \& Wang, 2012; Kramar, 2014). This can be observed in the strategy adopted by the European Union in Lisbon in 2000 (Lisbon strategy, 2010) and Europe 2020 (Europe 2020 strategy,2010).

The intention of the presented study is to improve knowledge about the problem of migration from the perspective of scholarship holders who, having spent a period of time abroad, returned to Serbia. So far, there have been no studies in the literature that have dealt with these issues. 
The aim of the study is to show the profile of scholarship students studying abroad and then returning to their home country. The study has analysed their motives for departure and return, as well as their perception of integration into the work environment in Serbia and utilisation of their knowledge.

The paper is composed of seven main sections. In the introductory section, the importance of knowledge in the contemporary world was pointed out and the purpose aa well as the goals of the study, which are related to the application of knowledge. The second section explains the importance of the temporary academic migration in the country and points out the problem of migration of highly educated experts from Serbia. In the third section a hypothetical - a methodological framework of the research is given. In the fourth chapter characteristics of the sample are presented. In the fifth chapter results of the study using statistical tools are shown. The intention was to highlight the main motives of scholarship holders to go abroad to study and return to their home country, as well as their perceptions of the possibilities to apply acquired knowledge and skills. The sixth section presents a discussion where the hypotheses and conclusions concerning them are summarised. Conclusions are given in the seventh section: how the obtained results can be generalised and what the limitations that have to be taken into consideration are.

\section{Analysis of the Impact of Migration of Highly Educated Experts}

\subsection{Overview of the Importance of Temporary Academic Migrations}

Through academic migrations, individuals acquire significant experience, knowledge, skills, establish valuable contacts with researchers from their own and related fields, and preserve different cultural forms. Academic migrations strongly influence the career of students, as well as their social life. The research conducted by the European Union ( he Erasmus Impact study, 2014), shows that the mobility of students plays a major role in the employment of students. Even $64 \%$ of employers underlined the tendency to delegate more demanding and responsible tasks to graduates who had "international" school "career". They also point out that mobility has an impact on the social life of students, and that even $33 \%$ of respondents who were mobile have partners of a different nationality. This range of qualities, brought by the exchange of experts through training, is, in fact, a product recognised as an investment in human resources. The exchange of highly qualified personnel and scientists, in particular, was increasing in the eighties and nineties of the last century, as a consequence of globalisation (Musikic, 2016:117-118). The migration of educated people can be permanent or temporary. Permanent migration refers to individuals who leave the country and never return to it, and it is commonly known as "brain drain". Temporary migration refers to the departure of young people for the purpose of education, whereby after completion of the scheduled time they return to their country and continue to work in it. The outcome of migrations in this respect depends on various factors.

Studies regarding the cause of the migration rely mainly on macro-structural "push-pull" theories (Pudar, Krstic, Radovanovic, 2015). Among push factors, operating in home countries, are poor social conditions, political instability, lack of meritocracy in the labour market which hinders employment opportunities for young talents, low pay, inadequate living and working conditions, the little prospect of professional development, etc. The strongest "brain drain" pull factors pertaining to host countries are globalization of knowledge, right social conditions, political stability, good job opportunities enriched with flexible career paths, higher pay, superior working conditions, higher level of job satisfaction, possibility for professional development, strong entrepreneurial culture and improved living standard (Filipovic, 2012:36).

Experts argue that the decision of a highly educated person to migrate is determined by the calculation of the investment return through the income, a gain of new knowledge and a better chance for employment (Grecic, 1999:14). Numerous researchers point out that highly educated returnees in several countries succeeded to a large degree in increasing national innovation capacity (Bodrozic, 2014:56). Lin (2010:123) calls that "the development of innovation capacity with the help of diaspora". King (2000) thinks that returnees can, through investments and innovations, contribute to the general welfare of the society in the countries of their origin.

Although the state has defined several strategies and measures that would reduce the brain drain, reports like the one from the World Economic Forum (World Economic Forum, 2016), show that the trend from the past decades is still present and that a large number of academically educated people leave Serbia, among them a highest percentage of medical doctors (Vasojevic \& Filipovic, 2017:191).

2.2. Migration of Highly Educated Personnel in the Republic of Serbia

In media, but also in the academic circles, warnings have been published that Serbia, due to such a high rate of departure of the most educated young people, remains without its own future. Considerably less fre- 
quently, highly educated young people who have decided to return to the country after education abroad are discussed.

Grecic (2005) points out that Serbia has traditionally been one of the emigration countries. Until the 1920 s moderate emigration was recorded, while the last 15 years indicate a galloping loss of human resources (Grecic, 2005:195). Filipovic estimates the number of Serbian scientific diaspora to be around $7000 \mathrm{PhDs}$ (Filipovic, 2012:143-144). According to Baird \& Klekowski von Koppenfels (2010:31), the question about the reasons for migration from Serbia has a multiple response, because migration decisions occur due to the complex social factors which include factors such as family and local communities. In the Strategy for education (Strategija Razvoja obrazovanja u Srbiji do 2020, 2012) the topic of migration is marginally mentioned, while in the Strategy for science this issue is mentioned, but there are no developed measures for its control (Istrazivanje za inovacije, 2016:22).

\section{Research in Real Terms}

\subsection{Hypothetical - Methodological Framework}

This research has been focused on defining the profile of post-academic and post-graduate scholarship holders who acquired their education abroad, on determining their reasons for their departure as well as their experiences upon returning to the country.

The defined hypotheses represent three pillars of research: a motive for education abroad, motives for returning home and applying acquired knowledge in the organisations in which they work. The authors assume that the main reason for students to study abroad is their desire for development and the inability to get scholarships to the desired scientific field in their own country. On the other hand, there is a presumption that the primary reason why scholarship holders return to their countries is of existential nature, defined through better opportunities for employment in comparison to those educated in Serbia. Based on these assumptions, the basic hypotheses are:

$\mathrm{H} 1$ : The desire for personal development through training, advancement of knowledge and experience is the main motive for education abroad.

$\mathrm{H} 2$ : Comparative advantage in the labour market and expectation of getting the desired job is an important factor why scholarship holders return to their country.

H3: Scholarship holders, through the realisation of their careers, influence the development of their organisations.

\subsection{Methodology of the Research}

For the purposes of this study, a questionnaire was constructed and distributed online. The questions were made in a way to examine the attitudes and opinions of scholarship holders that studied abroad. The questionnaire contained 20 questions, based on open and closed type answers. The first part of the questionnaire contained personal data of respondents: age, level of education, work organization, education level of parents, existence of a contract on compulsory return, connection with scholars in the country, departure motive, reason for returning, the idea about how to better apply knowledge, job position.

The second part of the questionnaire contained questions which were expressed in the degrees of fulfilment of the claim (from the lowest to the highest) about: job satisfaction, satisfaction with life, participation in decision-making, application of knowledge at work, acceptance from colleagues, level of education abroad, feeling that something is different, impact on employment, use of acquired contacts at work and contact with colleagues from abroad.

The study was conducted on the territory of the Republic of Serbia. In the first step, the goal was a selection and mapping of the research population. Post-graduate student scholars were the target group because of the expectations that there was a database of scholars that would facilitate the acquisition of the research sample. It was discovered that the database on scholarship holders that studied abroad using the Republic funds or foreign donor funds does not exist and that was the problem in the research. Using an online survey, the study involved 96 scholarship holders educated abroad. The data were analysed using methods of descriptive statistics and factor analysis (programmess: IBM SPSS and MS EXCEL).

The presented survey reports contain certain limitations which have to be taken into consideration: non-existence of scholarship database (Krnjaic, 2002: 184) emphasizes the lack of data on the number of highly educated young people and even student scholars who went abroad, inability to reach more students scholarship holders, a relatively small number of respondents, a general sample selection problem of online surveys with lack of personal interactions to verify accuracy of answers, non-existence of similar re- 
search in the region. The sample size is also limited and because the subject of the study were scholars from the group of the most successful students, whose population is not numerous.

\section{Research - the Sample Description}

The sample report according to age, gender, the area of completed studies and working organisation is given in Table 1.

Table 1: Characteristics of examinees

\begin{tabular}{|c|c|c|}
\hline Gender & Number & Percentage \\
\hline Male & 47 & 49.0 \\
\hline Female & 49 & 51.0 \\
\hline In total & 96 & 100.0 \\
\hline Age structure & Number & Percentage \\
\hline $20-30$ & 7 & 7.0 \\
\hline $30-40$ & 12 & 13.0 \\
\hline $40-50$ & 19 & 20.0 \\
\hline $50-60$ & 26 & 27.0 \\
\hline Older than 60 & 32 & 33.0 \\
\hline In total & 96 & 100.0 \\
\hline The area of completed studies & Number & Percentage \\
\hline Social sciences & 31 & 32.3 \\
\hline Natural sciences & 26 & 27.1 \\
\hline Medical sciences & 17 & 17.7 \\
\hline Engineering Sciences & 16 & 16.7 \\
\hline Veterinary science & 2 & 2.1 \\
\hline Other & 4 & 4.1 \\
\hline In total & 96 & 100.0 \\
\hline Working institution & Number & Percentage \\
\hline Faculty & 32 & 33.3 \\
\hline Scientific institutions & 24 & 25 \\
\hline Private sector & 21 & 21.9 \\
\hline Universities & 12 & 12.5 \\
\hline State Administration & 5 & 5.2 \\
\hline Medical institutions & 2 & 2.1 \\
\hline In total & 96 & 100 \\
\hline
\end{tabular}

Work institutions are mostly faculties, scientific institutions and universities. The study of Djuric shows the significance that people with the highest academic titles have for the sectors of economy and research in developed countries, unlike ours - where they mostly find jobs at universities and faculties (Djuric, 2015: 152). The largest percentage of respondents were educated social sciences. The social environment is considered important for the development of an individual; the role of parents and families is generally a common subject of theoretical considerations for educators, psychologists and sociologists. Research has shown that the highest percentage of respondents, $79.2 \%$, come from the educated backgrounds. Such a large number of students from the most educated families is quite expected, considering the long-term selfreproduction of the educational elite in Serbia. This corroborates the "closing of the classes" education as a channel of the social mobility for the lower social strata (Matejic-Djuricic \& Filipovic, 2014).

Scholarship holders are mostly funded by foreign Governments and Funds, less by the Government of the Republic of Serbia. Foreign Governments and Funds in most cases do not impose an obligation on scholars to return to their country after graduation, while the Fund for Young Talents of the Republic of Serbia "Dositeja" defines this request in scholarship contracts. It is in this way that the "Dositeja" fund protects the resources invested in education and formation of educational elite, given that the budget funds of the Republic of Serbia are in question, and, on the other hand, seeks to mitigate the consequences of "brain drain" (Odluka o obrazovanju Fonda za mlade talente, 2008).

After completing their studies abroad, most of the respondents, $79 \%$, did not continue their education, while $13 \%$ continued their education abroad, and only $8 \%$ in Serbia.

\section{Results}

Hypothesis 1 is analysed descriptively in Section 5.1. Hypothesis 2 is analysed descriptively and through factor analysis in Section 5.2. (included 5.2.1.). The hypothesis 3 is descriptively analysed in Section 5.3. 


\subsection{Motives for Studying Abroad}

Results are shown in Table 2 which presents the reasons why respondents chose to study abroad. It can be seen that the most common reason for choosing to study abroad was the desire to gain professional experience in another country, their perception of the quality of studying abroad, and the inability to study in the desired scientific areas in Serbia.

Table 2: Distribution of respondents according to motive to study abroad

\begin{tabular}{|l|c|c|}
\hline \multicolumn{1}{|c|}{ Departure motive } & Number & Percentage \\
\hline Quality of studies & 25 & 26.0 \\
\hline Inability to study within specific fields in the country & 18 & 18.8 \\
\hline Other country experience & 31 & 32.3 \\
\hline Network of contacts & 1 & 1.0 \\
\hline Departure from Serbia & 9 & 9.4 \\
\hline Requirement of the workplace & 1 & 1.0 \\
\hline Parents who live abroad & 3 & 3.1 \\
\hline Internationally accepted diploma & 6 & 6.3 \\
\hline Something else & 2 & 2.1 \\
\hline In total & 96 & 100.0 \\
\hline
\end{tabular}

The number of respondents who had no contractual obligation to return to their country after completing their studies was $65.6 \%$, while $34.4 \%$ of them had a contractual obligation of compulsory return to the country. The obtained results confirm the hypothesis 1 .

\subsection{Motives for Returning to Serbia}

The research aimed to highlight the reasons that influence scholarship holders to decide to return to Serbia after completing their studies abroad, Table 3.

Table 3: Distribution of respondents according to the reason for returning to Serbia

\begin{tabular}{|c|c|c|}
\hline The reason & Number & Percentage \\
\hline Family & 25 & 26.04 \\
\hline $\begin{array}{c}\text { The belief that I have a good } \\
\text { chance in Serbia }\end{array}$ & 18 & 18.75 \\
\hline Inability to stay abroad & 16 & 16.67 \\
\hline It is fine here & 11 & 11.46 \\
\hline $\begin{array}{c}\text { There was a chance for } \\
\text { employment }\end{array}$ & 10 & 10.42 \\
\hline Contract, workplace in Serbia & 10 & 10.42 \\
\hline Something else & 3 & 3.13 \\
\hline No answer & 3 & 3.13 \\
\hline In total & 96 & 100 \\
\hline
\end{tabular}

The main reason for return was related to family $(26.04 \%)$, followed by their belief that they have a good chance in Serbia (18.75\%). It can be seen that only $16.67 \%$ of respondents could not remain abroad for any reason, while others could, but they did not do that due to the reasons set out in Table 3.

A large number of respondents believe that education abroad had an impact on obtaining their jobs, exactly 44 of them, while 27 believe the opposite. The vast majority of respondents, $95 \%$ of them, said they had developed their competencies.

\section{Determination of the main factors for the return to the country}

The factor analysis is used in order to more comprehensively perceive the survey results. This technique allows analysing interrelationships among a large number of interrelated variables explaining these relationships regarding a smaller number of latent variables called factors. After checking the feasibility of using the method, (KMO=0.601; Bartlett's Test of Sphericity: Approx. Chi-Square $=415.052, \mathrm{df}=153, \mathrm{Sig}=0.00$.) the factor analysis was conducted on 18 variables. Using principal components analysis based on the determined characteristic equations, only five factors are considered as essential for further analysis. After Varimax orthogonal rotation, a factorial matrix was obtained, Table 4. 
Table 4: Rotated Component Matrix ${ }^{\mathrm{a}}$

\begin{tabular}{|c|c|c|c|c|c|}
\hline \multirow{2}{*}{ Variables } & \multicolumn{5}{|c|}{ Component } \\
\cline { 2 - 6 } & $\mathbf{1}$ & $\mathbf{2}$ & $\mathbf{3}$ & $\mathbf{4}$ & $\mathbf{5}$ \\
\hline $\mathrm{X} 1$ & .831 & .044 & -.129 & -.024 & .184 \\
\hline $\mathrm{X} 2$ & .775 & .012 & -.148 & -.003 & .044 \\
\hline $\mathrm{X} 3$ & .763 & .039 & .119 & -.024 & .037 \\
\hline $\mathrm{X} 4$ & .733 & -.033 & .098 & .035 & .121 \\
\hline $\mathrm{X} 5$ & .619 & .256 & .105 & .073 & -.110 \\
\hline $\mathrm{X} 6$ & .014 & .806 & -.234 & .077 & .087 \\
\hline $\mathrm{X} 7$ & -.290 & -.667 & -.008 & .189 & -.320 \\
\hline $\mathrm{X} 8$ & .029 & .649 & .073 & -.054 & -.195 \\
\hline $\mathrm{X} 9$ & .160 & .234 & .694 & -.307 & -.095 \\
\hline $\mathrm{X} 10$ & .033 & .161 & -.590 & .001 & -.192 \\
\hline $\mathrm{X} 11$ & -.206 & -.124 & .577 & .293 & .067 \\
\hline $\mathrm{X} 12$ & .408 & .015 & .507 & .099 & -.140 \\
\hline $\mathrm{X} 13$ & .175 & -.181 & -.099 & .663 & -.160 \\
\hline $\mathrm{X} 14$ & .006 & -.040 & .072 & .626 & .241 \\
\hline $\mathrm{X} 15$ & -.187 & .284 & .068 & .601 & -.354 \\
\hline $\mathrm{X} 16$ & -.117 & .162 & .122 & -.066 & .752 \\
\hline $\mathrm{X} 17$ & .225 & .022 & .207 & .344 & .525 \\
\hline $\mathrm{X} 18$ & .113 & -.087 & -.074 & -.043 & .450 \\
\hline
\end{tabular}

Extraction Method:Principal Component Analysis.

Rotation Method: Varimax with Kaiser Normalization.

a. Rotation converged in 6 iterations.

The interpretation of the main factors is given in Table 5

Table 5: Interpretation of the main factors

\begin{tabular}{|c|c|}
\hline Variables & Interpretation \\
\hline Job satisfaction & \multirow{5}{*}{ Satisfaction with work and life } \\
\hline Satisfaction with life & \\
\hline Participation in decision making & \\
\hline Application of knowledge at work & \\
\hline Acceptance from colleagues & \\
\hline Work organization & \multirow{3}{*}{$\begin{array}{c}\text { Work organization and existence of a } \\
\text { compulsory return contract }\end{array}$} \\
\hline Level of education abroad & \\
\hline The existence of a contract on compulsory return & \\
\hline Connection with scholars in the country & \multirow{4}{*}{ Perception of better position in the country } \\
\hline The motive for going abroad & \\
\hline Feeling different & \\
\hline The impact on employment & \\
\hline The use of acquired contacts at work & \multirow{3}{*}{$\begin{array}{l}\text { Existing contacts with foreign colleagues and } \\
\text { networking }\end{array}$} \\
\hline The education of parents & \\
\hline Contact with colleagues from abroad, & \\
\hline Reason for returning & \multirow{3}{*}{ Family and job position } \\
\hline The idea about how to better apply knowledge & \\
\hline Job position. & \\
\hline
\end{tabular}

By applying the method of factor analysis we have discovered that the return of scholarship holders is mostly influenced by the following factors: satisfaction with work and life, work organization and existence of a compulsory return contract, perception of better position in the country, existing contacts with foreign colleagues and networking and family and job position (the main reason for returning is family, table 3). The obtained results confirm the hypothesis 2.

\subsection{Perception of Students about their Lives and Possibilities to Apply Knowledge}

Numerous authors indicate the difficulties of repatriation and deal with the phenomenon of „reverse cultural shock" (Oberg, 1960:177-182). Some studies state that with repatriation the idea of "returning home" is an illusion and that it is characterised by the absence of happiness and dissatisfaction. Each individual process of repatriation can be observed through "social recurrence" which has as its aim the creation of future in the country of origin (for example Dürrschmidt, 2016; Stefansson, 2004). 
The evaluation of the opportunities of respondents to use the acquired knowledge at their work places are presented in Table 6 . This can be seen as an attempt to show the openness of work environment towards those who studied abroad. Most of the respondents, $44.8 \%$, point out they need a better job in order to use all acquired knowledge, $25 \%$ of them say that there is no possibility to use the acquired knowledge while $27.1 \%$ of them believe they are using the acquired knowledge in solving and performing business tasks. These results only partially confirm the hypothesis 3 , since only $27 \%$ of the respondents consider that they have the opportunity to apply their knowledge in their organisation. This distribution indicates that business and academic environment in Serbia is not sufficiently open towards the wishes of scholars who returned to Serbia.

Table 6: Better application of knowledge

\begin{tabular}{|c|c|c|c|c|}
\hline & Frequency & Percent & $\begin{array}{c}\text { Valid } \\
\text { Percent }\end{array}$ & $\begin{array}{c}\text { Cumulative } \\
\text { Percent }\end{array}$ \\
\hline Something else & 1 & 1.0 & 1.0 & 1.0 \\
\hline No possibility & 24 & 25.0 & 25.0 & 26.0 \\
\hline Better position & 43 & 44.8 & 44.8 & 70.8 \\
\hline $\begin{array}{c}\text { In the foreign } \\
\text { company }\end{array}$ & 2 & 2.1 & 2,1 & 72.9 \\
\hline Already apply & 26 & 27.1 & 27.1 & 100.0 \\
\hline Total & 96 & 100.0 & 100.0 & \\
\hline
\end{tabular}

In order to determine the level of satisfaction with life in Serbia of the former scholarship holders who studied abroad, depending on the reason for their return to the country, the ANOVA statistical test was applied. A statistically significant difference was obtained as regards the level of life satisfaction of scholars, depending on the reason for their returning to the country, Figure 1.

The most satisfied with life in Serbia were scholarship holders who returned because of the family, followed by those for whom for some reason it was impossible to stay abroad. The least satisfied with life in Serbia were scholarship holders who had to return due to a contract with the work organisation.

\section{Discussion}

According to Popovic \& Maletic \& Paunovic (2015), the main factors which influence job satisfaction of the employees are interpreted as interpersonal relationships, development opportunities, reward system, job exhaustion, and employee awareness. According to Hertzberg's Two-Factor Theory of Motivation (2017), hygiene factors of motivation (wages, work conditions, business policy, company organisation) do not lead to positive satisfaction in the long-term. The motivators symbolised the psychological needs that were perceived as an additional benefit (Furnham \& Eracleous \& Chamorro-Premuzic, 2009). Motivational factors include: challenging work, opportunity to learn new things, promotion, recognition, etc. (Janicijevic, 2008).

The obtained results showed that scholarship holders go abroad mostly because of their desire for personal improvement and acquisition of new experiences, and because of inability to study within specific fields in the country. This coincides with the motivators of Hertzberg's Two-Factor Theory of Motivation. Consequently, Hypothesis 1 is proven.

To achieve personal and career goals, apart from formally and informally acquired knowledge, other requirements are important nowadays, such as continuous learning through experience, developing social skills, improving decision-making processes through managing the increasing amount of information. (Kirin \& Janovac \& Sedmak \& Jakic, 2014:264). The obtained main factors for the return which scholarship holders who studied abroad and returned to the country describe are: job and lifestyle satisfaction, working contract, believing that studying abroad has a positive effect on their employment, acquired contacts and motivation for return that are significantly related to family, and believing in good chances for the future. The major reasons why students - scholarship holders return to their country are the expectation of obtaining the desired job and the ability to work in the desired field of study. Reasons for return related to work occur in over $50 \%$ cases which confirm the $\mathrm{H} 2$ hypotheses of this research.

Important reasons why scholarship holders return to their countries are family reasons, and the research has shown that those who returned because of their family were most satisfied with their life. This can partly be explained because of the mainly collectivist national culture in Serbia (Janicijevic, 2008). The research has shown that the method and type of training, type of scholarship, the level of acquired qualifications, and continuation of education after returning home depend on the work organisation. 
The research showed that the majority of scholarship holders, about $70 \%$ maintain that it is necessary to have a better work position to be able to apply all the acquired knowledge. Otherwise, there is no possibility to use all the acquired knowledge in their work organisation. In this way, hence, we have only partially confirmed the H3 hypothesis. In order for scholarship holders to influence the development of their work organisations, it is necessary to view their knowledge as a valuable resource and to use it in a more adequate manner.

\section{Conslusion}

"Motivation and satisfaction of employees have become the basis for the stability of modern companies. Dissatisfied workers may not provide the growth and development of the company, and the presence of dissatisfaction is an important indicator of future problems. Understanding the issues of job satisfaction is essential for the design of the workplace, implementing organisational culture, creating motivation system and reward system and defining management style" (Kirin \& Mitrovic \& Borovic \& Sedmak, 2016:819)

The research highlighted problems that scholarship holders have after returning to the country: low applicability of what has been learnt and unclear idea about skills for work development. Most of them think that they should have a better work position to be able to apply all the acquired knowledge, or that there is no possibility to apply the acquired knowledge in their work organisation. Also, most of the respondents are not satisfied enough with their work.

The obtained motives for return after studying in more developed countries, as well as the problems with which scholarship holders meet after return, are similar in countries of similar national cultures, those that do not have developed economies and favourable job offers. Therefore, the results obtained can be generalised to countries that are undergoing or have recently commenced a transition and are similar in cultural characteristics.

The presented survey reports have certain limitations that have to be taken into consideration while interpreting final results. Concerning online surveys, the following challenges have to be mentioned: insufficient outreach to be representative of all scholarship holders, general sample selection problem of online surveys (underrepresentation), a non-existing database of scholarship holders, lack of personal interactions to verify the accuracy of answers.

As there were no studies that have dealt with this topic, the presented study gave some answers and opened up a number of questions about the phenomenon of temporary "brain gain" migrations. Considering the importance of the problem, future research should integrate all stakeholders: government, economic sector, scientific organisations, local communities, people from the diaspora, etc. with the aim to create the appropriate environment for better knowledge management. According to (Filipovic, 2012:166) the best way to transform brain drain into brain gain is through brain chain (networks).

\section{REFERENCES}

[1] Alagaraja, M., \& Wang, J. (2012). Development of a national HRD strategy model: Cases of India and China. Human Resource Development Review, 11(4), 407-429. DOI: 10.1177/1534484312446190

[2] Baird T.E. \& Klekowski von Koppenfels a. (2010). The Serbian Diaspora and Youth: Cross-Border Ties and opportunities for Development, Final report prepared within the MDG Joint Programme Youth Employment and Migration in Serbia. Unpublished. Retrieved from: http://ec.europa.eu/europe2020/pdf/lisbon_strategy_evaluation_en.pdf

[3] Bartlett, M.S.(1954). A note on the multiplying factors for various chi-square approximations.Journal of Royal Statistical Society, Series B,16( 2), 296-298.

[4] Bodrozic, Z. (2014). Povratak visoko obrazovanih strucnjaka u Srbiju. Psiholoska istrazivanja, 7(1), 5575.DOI:10.5937/PsIstra1401055B

[5] Djuric, M. B. (2015). Human capital quality indicators of the Serbian scientific community at home and abroad (published Phd thesis). University of Belgrade, Faculty of organizational sciences, Belgrade

[6] Durrschmidt, J. (2016). The irresolvable unease about be-longing: Exploring globalized dynamics of homecoming. The Sociological Review, 19(5),495-510. DOI:10.1177/1367549416631553

[7] Europa 2020 strategy. (2010). Retrieved from:https://ec.europa.eu/info/strategy/europeansemester/framework/europe-2020-strategy_en

[8] Filipovic, J. (2012). Management of a Diaspora Virtual University as a Complex Organization: Serbian Diaspora Virtual University: An Emerging Leadership of a Nation. LAP Lambert Academic Publishing: Germany 
[9] Furnham, A., Eracleous,\&. Chamorro-Premuzic, T. (2009). Personality, motivation and job satisfaction: Hertzberg meets the Big Five. Journal of managerial psychology, 24(7-8), 765-779. DOI: $10.1108 / 02683940910996789$.

[10] Grecic,V. (1999). „Odliv mozgova ”ili „cirkulacija“ visokostrucnih i naucnih kadrova. Ekonomska analiza: org. Ekonomskog fakulteta u Beogradu, 43 (140), 13-27.

[11] Grecic, V. (2005). Upravljanje znanjem: nova strategija „koriscenjaumova“ iz dijaspore. Poslovna inteligencija: osnovna uspesnost menadzmenta u globalnim uslovima, 187-210.

[12] Herzberg's Two-Factor Theory of Motivation, Retrieved from: http://www.managementstudyguide.com/herzbergs-theory-motivation.htm

[13] Istrazivanje za inovacije. (2016). Strategija naucnog i tehnoloskog razvoja Republike Srbije za period 2016-2020. Ministarstvo prosvete, nauke i tehnoloskog razvoja.

[14] Janicijevic,N. (2008). Organizational behavior. Belgrade: Data Status

[15] King,R. (2000). Generalizations from the history of return migration. In B. Ghosh (Ed.), Return migration: Journey of hope or despair?, 7-55.Retrieved from:http://www3.weforum.org/docs/gcr/20152016/SRB.pdf

[16] Kirin,S., Mitrovic,M., Borovic,S. \& Sedmak, A. (2016).Impact Of The Life Cycle Of Company To Job Satisfaction,Tehnicki Vjesnik, 23(3),819-825. DOI: 10.17559/TV-20140715103959

[17] Kirin,S.,Janovac,T.,Sedmak,A..\& Jakic,B. (2014,Novembar10-11). Research of knowledge and skills effects on achievement of employee's aims, TEAM2014 Kecskemét, 264-269.

[18] Kramar, R. (2014). Beyond strategic human resource management: is sustainable human resource management the next approach?. The International Journal of Human Resource Management, 25(8), 1069-1089. DOI: 10.1080/09585192.2013.816863

[19] Krnjaic, Z.(2002): Intelektualna nadarenost mladih. Beograd: Institut za psihologiju. DOI:159.95.072

[20] Lin, X. (2010). The diaspora solution to innovation capacity development: Immigrant entrepreneurs in the contemporary world. Thunderbird International Business Review, 52(2),123-136. DOI:10.1002/tie.20319

[21] Lisbon Strategy (2010). Strategy evaluation document Commission staff working document.Retrieved from: http://ec.europa.eu/europe2020/pdf/lisbon strategy evaluation en.pdf

[22] Matejic-Djuricic Z., Filipovic M. (2014). Ekspanzija skolovanja: realnosti privid jednakih sansi u dostupnosti obrazovanja. Beograd: Socioloski pregled, 1, 87-103.

[23] Musikic,S.(2016), Uticaj procesa tranzicije na nezaposlenost mladih u Republici Srbiji. Doktorski rad. Beograd: Fakultet za menadzment, Beograd.

[24] Oberg,K.(1960). Cultural Shock: Adjustment to New Cultural Environments. Practical Anthropology 7(4), 177-182. DOI:10.1177/009182966000700405

[25] Odluka o obrazovanju Fonda za mlade talente. (2008). Sluzbeni glasnik Republike Srbije. 71/2008

[26] Popovic,B., Maletic,R., \& Paunovic,T. (2015). Employee Satisfaction Survey in Function of Business Improvement. Management: Journal of Sustainable Business and Management Solutions in Emerging Economies, 20(76), 31-40. DOI:10.7595/management.fon.2015.0021

[27] Pudar, D., Krstic, G., Radovanovic, N.(2015), Studiranje u inostranstvu i povratak u Srbiju. Studija 2. Beograd: Institu ekonomskih nauka.

[28] Stefansson, A. H. (2004). Homecomings to the future: From diasporic mytographies to social projects of return. In F.Markowitz \& A.H. Stefansson (Eds.), Homecomings:Unsettling paths of return (pp. 2-20). USA: Lexington Books

[29] Strategija Razvoja obrazovanja u Srbiji do 2020. (2012). Sluzbeni glasnik Republike Srbije, broj 1. $107 / 2012$.

[30] The Erasmus Impact Study. Luxembourg: Publications Office of the European Union. (2014). Retrieved from : http://ec.europa.eu/education/library/study/2014/erasmus-impact_en.pdf

[31] Vasojevic,N.,\& Filipovic,M. (2017). Studenti medicine, korisnici drzavnih stipendija Republike Srbije, i njihovo skolovanje u 21. veku: Mogucnost poboljsavanja. Sociologija, 59(2),189-205. DOI: 10.2298/SOC1702189V

[32] World Economic Forum (2016). The global competitiveness report 2015-2016, World economic forum Geneva Retrieved from: http://www3.weforum.org/docs/gcr/2015-2016/SRB.pdf 


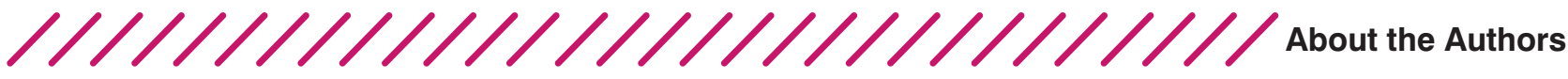

\author{
Nena A. Vasojevic \\ Innovation Center of the Faculty of Mechanical Engineering, University of Belgrade \\ Mail: nenavasojevic@hotmail.com
}

Nena A. Vasojevic (1988) is a the Ministry of Education, Science and Technological Development of the Republic of Serbia scholarship holder. Also, she is a research fellow at the science project organized by the Faculty of Mechanical Engineering at the

University of Belgrade. She is currently pursuing her Ph.D. at the department of the History and Philosophy of Natural Sciences and Technology, the University of Belgrade,

Serbia. Her areas of interest include: human resources, polite education and research methodology.

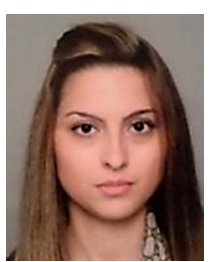

Snezana Kirin Innovation Center of the Faculty of Mechanical Engineering, University of Belgrade Mail: skirin@mas.bg.ac.rs

Snezana Kirin is a senior research associate at the Innovation Centre of the Faculty of Mechanical Engineering in Belgrade. She is the author of about 100 scientific papers, 15 of which are on the SCI list. She has been involved in several research projects (national and international). Her research interests include management, risk management, human resource management, organizational behaviour.

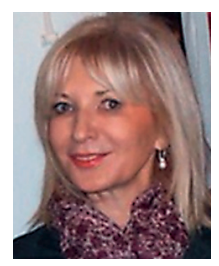

Predgrad J. Marković Institute for Contemporary History, Belgrade Mail: predragjmarkovic@yahoo.com

Predrag J. Marković (1965) is a Senior Research Fellow at the Institute for Contemporary History, Belgrade, where he works on social and cultural history, incliuding history of education. He teaches at several universities as a visiting professor. $\mathrm{He}$ has written several books and more than 90 academic articles. Also, he is the author of the numerous TV education programs and a columnist for the

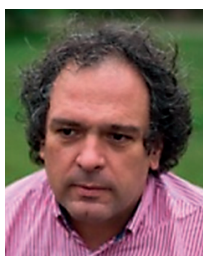
oldest national newspaper Politika. 